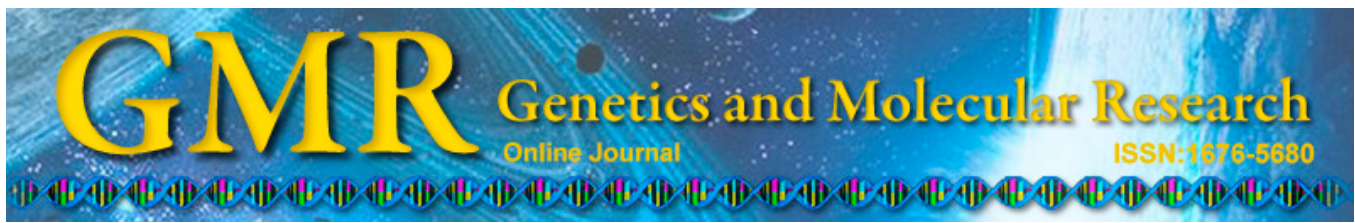

\title{
Novel DNA extraction assay for molecular identification of Aedes spp eggs
}

\author{
M.T.S. Freitas ${ }^{1}$, P.P. Gomes-Júnior ${ }^{1,2}$, M.V.A. Batista ${ }^{5}$, T.C. Leal-Balbino ${ }^{3}$, \\ A.L. Araujo ${ }^{4}$ and V.Q. Balbino ${ }^{1}$ \\ ${ }^{1}$ Departamento de Genética, Universidade Federal de Pernambuco, Recife, \\ PE, Brasil \\ ${ }^{2}$ Unidade Acadêmica de Serra Talhada, \\ Universidade Federal Rural de Pernambuco, Serra Talhada, PE, Brasil \\ ${ }^{3}$ Departamento de Microbiologia, Centro de Pesquisas Aggeu Magalhães, \\ Fundação Oswaldo Cruz, Recife, PE, Brasil \\ ${ }^{4}$ Fundação Nacional de Saúde, Secretaria de Saúde, Serra Talhada, PE, Brasil \\ ${ }^{5}$ Departamento de Biologia, Universidade Federal de Sergipe, São Cristóvão, \\ SE, Brasil
}

Corresponding author: V.Q. Balbino

E-mail: valdir@ufpe.br

Genet. Mol. Res. 13 (4): 8776-8782 (2014)

Received October 9, 2013

Accepted May 14, 2014

Published October 27, 2014

DOI http://dx.doi.org/10.4238/2014.October.27.19

\begin{abstract}
Aedes aegypti and A. albopictus represent the two most important species of mosquitoes in relation to dengue virus transmission both in the Americas and Asia. However, the study of theses species generally requires the establishment of a colony for the larvae to hatch, or waiting for the adult development to perform its taxonomic classification, which is time consuming. Thus, the establishment of new methods aimed at obtaining DNA directly from the mosquito eggs is relevant. Accordingly, we compared a new approach based on Chelex ${ }^{\circledR}$ 100 resin with the standard STE method to extract DNA from the eggs of Aedes spp to molecularly identify these vectors. The Chelex ${ }^{\circledR} 100$ resin approach was very efficient, as satisfactory amounts of DNA were obtained, making it possible to amplify and sequence a mitochondrial
\end{abstract}


DNA barcode region widely used to identify species. The STE protocol yielded substantial amounts of DNA, but the 260/280 optical density ratio indicated a low quality, precluding amplification. This new method proved quite effective in obtaining DNA from even a single mosquito egg, and it can thus be applied in population genetic studies of various vector insects to enhance monitoring programs.

Key words: Epidemiologic surveillance; Molecular identification; Aedes sp

\section{INTRODUCTION}

Aedes aegypti and $A$. albopictus mosquitoes are of great importance regarding dengue transmission, a disease that affects more than 100 countries. In the Americas, in 2010, approximately 1.6 million cases were reported, of which 49,000 were considered severe. In addition, these insects are proven to be involved in the transmission of Chikungunya and yellow fever viruses (Gubler, 2006; Paupy et al., 2010).

Aedes spp are found mainly in urban areas, and they develop primarily in clean water reservoirs and small temporary pools (Nelson, 1986). Generally, it is necessary to use taxonomic keys that describe morphological characteristics of certain phases of the animal's life, especially the larval or adult phases, for the identification of the mosquitoes (Guedes, 2006). However, this process requires ideal water and temperature conditions and/or waiting for the larvae to reach an ideal stage for identification, which is time consuming (Cary, 1996). While the maintenance of the environmental conditions could be regulated, some eggs can exhibit a natural delay in their cycle, or even never hatch, making it necessary to use auxiliary techniques for larval release (Forattini, 1962; Charles, 1967; Swartz and Hebert, 1987; Gomes et al., 1995; Chung, 1997). Another possible approach would be the analysis of the morphological characteristics of the egg exochorion, which requires an expert in egg morphological analysis, and expensive equipment (Reinert, 1972).

In recent decades, researchers have been increasingly more likely to solve taxonomic problems in certain species using polymorphic genetic markers, also widely used in phylogenetic studies and population genetics (Yue and Orban, 2001; Aranishi and Okimoto, 2006). One of the most used genes is mitochondrial cytochrome oxidase I (COI), which has high phylogenetic signal and rapid evolutionary rate, which is important for characterizing populations, subspecies and species (Harrison, 1989). Therefore, Hebert et al. (2003) proposed that COI should serve as a barcode for metazoans, making it a universal system for species molecular taxonomy (Miller, 2007).

Accordingly, this study aimed to compare a new method of DNA extraction of Aedes eggs based on the use of Chelex ${ }^{\circledR} 100$ resin and the standard STE method to obtain genomic DNA. The resin method proved extremely efficient since satisfactory amounts of DNA were obtained, making it possible to amplify and sequence the DNA barcode.

\section{MATERIAL AND METHODS}

\section{Egg achievement and DNA extraction}

A total of 742 eggs of Aedes mosquitoes were used, of which 636 belonged to Aedes 
aegypti and 106 to A. albopictus. Initially, 318 A. aegypti unviable eggs (dry and open) were screened. The eggs were collected using ovitraps in the city of Serra Talhada $\left(7^{\circ} 59^{\prime} 31^{\prime \prime S}\right.$, $38^{\circ} 17^{\prime} 54^{\prime \prime W}$ ) following a protocol described elsewhere (Fantinatti et al., 2007). Serra Talhada is located in the semi-arid region of the state of Pernambuco, Northeast Brazil. Viable eggs of the Rockefeller lineage and A. albopictus were obtained from the insectary of the Centro de Pesquisas Aggeu Magalhães, Fundação Oswaldo Cruz, Brazil. DNA was extracted with Chelex ${ }^{\circledR} 100$ (BioRad, Berkeley, CA, USA) using viable and unviable $A$. aegypti eggs in triplicate, in the amounts of $1,5,10,20,30$, and 40 eggs, providing 36 samples. In addition, 36 samples of $A$. albopictus were used without replicates.

The method used for individual or grouped eggs followed that of Walsh et al. (1991), with modifications. Briefly, the eggs were placed in $1.5-\mathrm{mL}$ plastic tubes with $100 \mu \mathrm{L} 5 \%$ Chelex ${ }^{\circledR} 100$ resin. The eggs were then macerated with a pestle until homogenized, and allowed to stand for $1 \mathrm{~h}$ in water bath at $54^{\circ} \mathrm{C}$. Subsequently, the mixture was transferred to a plastic tube and kept at $94^{\circ} \mathrm{C}$ for $30 \mathrm{~min}$ in a Multigene OptiMax Thermal Cycler TC 9610 (LABNET, Edison, NJ, USA). The solution was then centrifuged at 13,000 rpm for 6 min, and the supernatant was transferred to a $1.5-\mathrm{mL}$ plastic tube, and stored at $-20^{\circ} \mathrm{C}$. In the STE protocol, viable eggs of $A$. aegypti were homogenized in STE buffer (10 mM Tris-HCl, $1 \mathrm{mM}$ EDTA, and $100 \mathrm{mM} \mathrm{NaCl}$ ), incubated for $10 \mathrm{~min}$ at $95^{\circ} \mathrm{C}$ and centrifuged at $13,000 \mathrm{rpm}$ for 1 min. Finally, DNA quantification was carried out in NanoDropTM 1000 spectrophotometer (Thermo Scientific, Waltham, MA, USA).

\section{Polymerase chain reaction}

Cytochrome oxidase I mitochondrial gene, associated with a DNA barcode (Hebert and Gregory, 2005) was amplified using the primers HCO2198-L (5'-TAAACTTCWGGRTGWC CAAARAATCA-3') and LCO1490-L (5'-GGTCWACWAATCATAAAGATATTGG-3') described by (Nelson et al., 2007). In general, $12.5 \mu \mathrm{L}$ Mix Go Taq Colorless (Promega, Fitchburg, WI, USA), $7.5 \mu \mathrm{L}$ nuclease-free water, $1.5 \mathrm{~mL}$ of each primer, and $2 \mu \mathrm{L}$ template DNA were used. The amplification reactions were carried out in a Multigene OptiMax Thermal Cycler TC 9610 with the following cycle: initial denaturation at $95^{\circ} \mathrm{C}$ for $3 \mathrm{~min} ; 35$ cycles of denaturation at $95^{\circ} \mathrm{C}$ for $30 \mathrm{~s}$, annealing at $44^{\circ} \mathrm{C}$ for $1 \mathrm{~min}$, and extension at $72^{\circ} \mathrm{C}$ for $1 \mathrm{~min}$; and a final extension at $72^{\circ} \mathrm{C}$ for $7 \mathrm{~min}$. The amplification products were analyzed by $1 \%$ agarose gel electrophoresis for $30 \mathrm{~min}$ at $100 \mathrm{~V}$. The electrophoretic gel was stained with $\mathrm{SYBR}^{\circledR} \mathrm{Safe}$ DNA Gel Stain (Invitrogen, Carlsbad, CA, USA), and visualized with a UV transilluminator.

\section{Amplicon purification and sequencing}

The amplicon purification was performed using the Wizard ${ }^{\circledR}$ SV Gel and PCR CleanUp System kit (Promega), following manufacturer instructions. Subsequently, purified amplicon sequencing was carried out in an ABI 3500 automated sequencer (Applied Biosystems, Cleveland, OH, USA). The sequences were then evaluated using the programs Pregap4 v 1.5 and Gap4 incorporated into the Staden Package (Staden, 1996), using a Phred value of 30 as a quality cutoff. Similarity searches in GenBank were performed using Blastn (Altschul et al., 1990). The sequences were deposited at the GenBank database (http://www.ncbi.nlm.nih. gov/), under the following accession Nos. JX456411 to JX456417. 


\section{RESULTS AND DISCUSSION}

The mean concentrations of DNA ranged from 6.8 to $192.9 \mathrm{ng} / \mu \mathrm{L}$ using Chelex ${ }^{\circledR} 100$ resin (data not shown). The STE method, consisting of lysis and denaturation steps, is efficient in extracting genomic DNA. Thus, it is employed in many types of insect studies where the samples are adult diptera (Dobson and Rattanadechakul, 2001; Pinto et al., 2013). Using the STE method, the average DNA concentrations obtained using a single egg were higher (22.8$92.2 \mathrm{ng} / \mu \mathrm{L}$ ) than with the Chelex ${ }^{\circledR} 100$ resin method, but DNA quality was significantly lower owing to the impurities not removed in this method, making the amplification step impossible. All samples obtained using Chelex ${ }^{\circledR} 100$ resin were amplified satisfactorily producing a fragment of approximately $708 \mathrm{bp}$ (negative control was a reaction without DNA, to ensure no contamination) (Figure 1). These primers were defined for the identification of insects, from the amplification of the region of the COI gene proposed by Nelson et al. (2007). All sequences showed 99 and $100 \%$ similarity with $A$. aegypti and A. albopictus sequences, respectively.

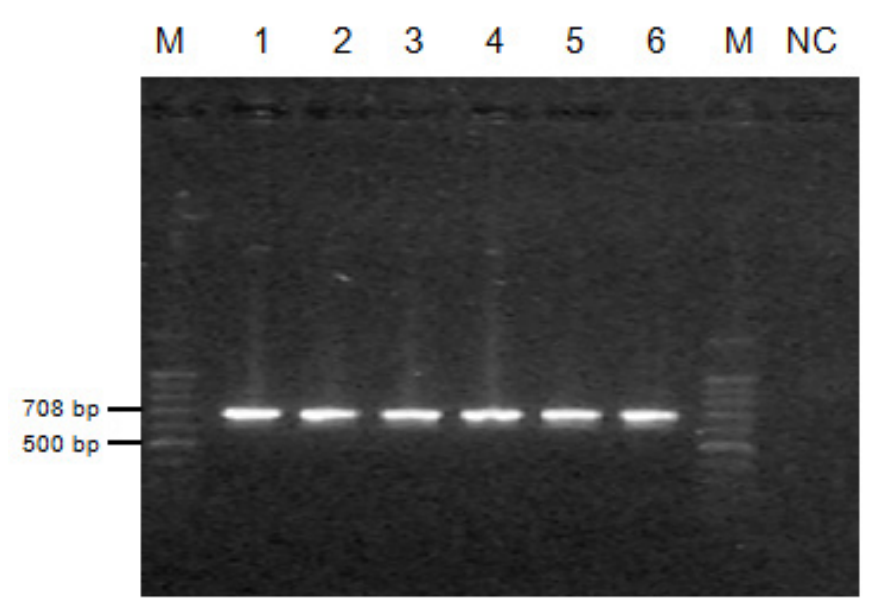

Figure 1. Electrophoresis gel showing the amplification product of Aedes albopictus DNA barcode region. Lane M $=$ molecular weight; lane $1=$ one single egg; lane $2=5$ eggs; lane $3=10$ eggs; lane $4=20$ eggs; lane $5=30$ eggs; lane $6=40$ eggs; lane $N C=$ negative control.

The results showed that DNA can be obtained from even one single egg of Aedes spp, regardless of their viability conditions because we also used eggs considered unviable for larval hatching in the laboratory. Thus, we developed a rapid, efficient and low-cost method that can be applied to the identification of vector mosquitoes. Traditionally, for the taxonomic identification of mosquitoes, a colony is necessary to obtain the larval or adult forms. However, there are a number of parameters that must be controlled, which otherwise can cause their natural cycle to slow down or even stop. This process could cause some viable eggs to never hatch under laboratory conditions. Moreover, a thorough analysis may be required in the egg excision, followed or not by the use of a larval whitening technique (Forattini, 1962; Charles, 1967; Swartz and Hebert, 1987; Gomes et al., 1995; Chung, 1997). Another way found for taxonomists to perform the identification of mosquito eggs is the use of existing morphological structures in the eggs, which have the potential to assist in the taxonomic identification of some species of medical interest. However, it is necessary to use a scanning electron microscope, 
which requires technical expertise in handling the equipment and in the analysis of the egg structures (Swartz and Hebert, 1987; Cary, 1996; Giangrande, 2003).

Methods for nucleic acids extraction from samples with cell wall chitin have been proposed as an alternative to the classical taxonomy of species of medical importance. In previous studies, great difficulty in obtaining DNA from both eggs and larvae has been reported, due to the presence of lipids in these tissues, which hamper DNA recovery and PCR (Reinert, 1972). This problem is even more evident when the eggs are degraded (Briski et al., 2011). Thus, researchers choose to lyse the eggs for release of larvae prior to DNA extraction using heat shock (Traub et al., 2009), saline (Buathong et al., 2010), autoclave techniques (Stensvold et al., 2006; Duenngai et al., 2008; Umesha et al., 2008) or crushing (Sato et al., 2009). Using this new method based on Chelex ${ }^{\circledR} 100$ resin described in this study, we could neutralize inhibitors, since regardless of the number of eggs, all samples were satisfactorily amplified. Furthermore, DNA concentrations and egg amounts used in this study were consistent. However, there is the possibility of variation in the DNA concentration due to manual maceration process, which is considered a critical step in the achievement of good quality DNA for PCR, as observed by other authors (Yue and Orban, 2001; Desloire et al., 2006).

Another relevant point in our study was that we used the COI gene, since several studies have been conducted primarily to understand the genetic dynamics of this vector populations, which is an important aspect for establishing monitoring and control strategies. That way, the use of DNA barcode in this study was very important because we can provide the appropriate conditions to differentiate these two species of mosquitoes. According to Hebert et al. (2003), there must be at least $3 \%$ polymorphic sites between nucleotide sequences, along with the appropriate model of nucleotide substitution for this molecular marker, for any metazoan species to be distinguished. In this study, we observed approximately 67 polymorphic sites (Figure 2), representing approximately $20 \%$ of the complete sequence alignment.

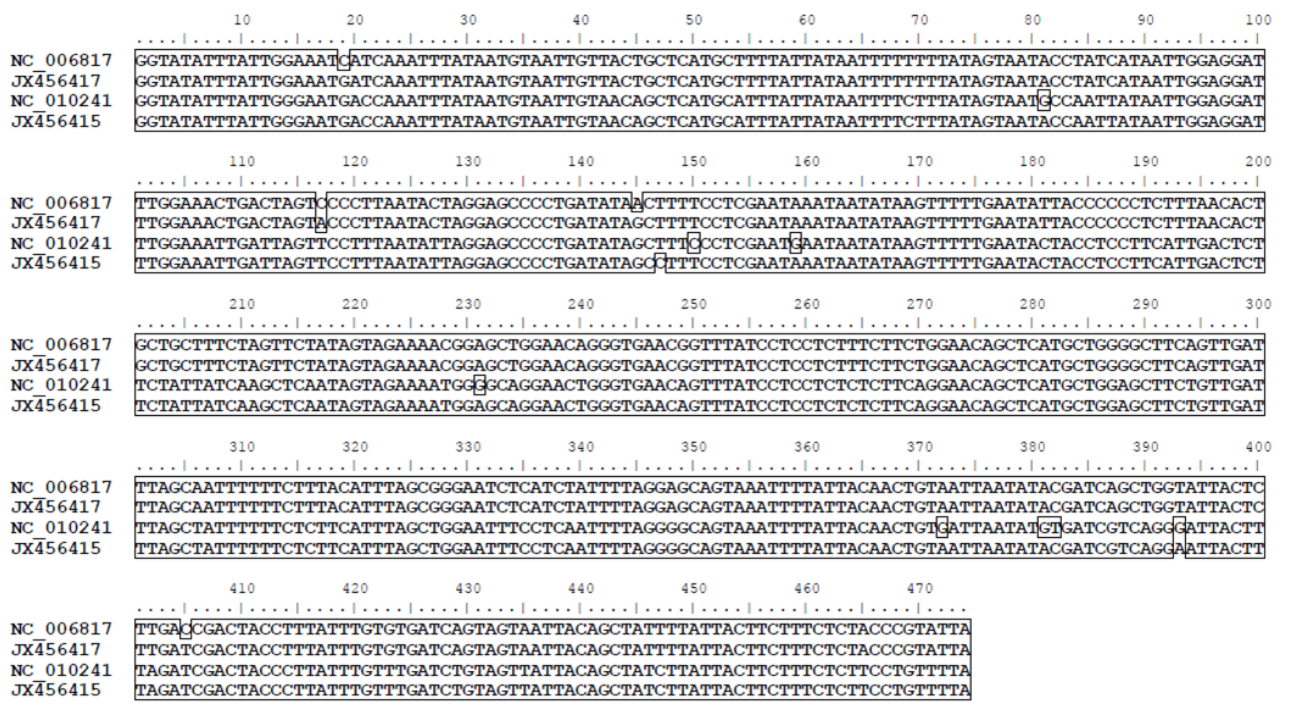

Figure 2. Multiple sequence alignment of Aedes aegypti and A. albopictus DNA barcode sequences. Two sequences obtained in this study and two reference sequences from GenBank are compared. The accession number is displayed. The outlined nucleotide bases are conserved. 
Therefore, using an efficient, simple, safe and low-cost method of DNA extraction, we could obtain DNA from viable or unviable eggs in appropriate quantity and quality for a good amplification reaction. Associated with this, we suggest the use of this new tool to study the population dynamics of mosquitoes of medical importance, and possibly to implement this new approach in programs for monitoring insecticide resistance in natural populations.

\section{ACKNOWLEDGMENTS}

Research supported by CNPq (\#142216/2010-0, fellowship for M.V.A. Batista and \#309124/2012-3 for V.Q. Balbino), FACEPE (\#APQ-0651-2.02/10 for V.Q. Balbino), and Universidade Federal de Pernambuco.

\section{REFERENCES}

Altschul SF, Gish W, Miller W, Myers EW, et al. (1990). Basic local alignment search tool. J. Mol. Biol. 215: 403-410.

Aranishi F and Okimoto T (2006). A simple and reliable method for DNA extraction from bivalve mantle. J. Appl. Genet. 47: 251-254

Briski E, Cristescu ME, Bailey SA and MacIsaac HJ (2011). Use of DNA barcoding to detect invertebrate invasive species from diapausing eggs. Biol. Invasions 13: 1325-1340.

Buathong S, Mungthin M, Tan-ariya P, Naaglor T, et al. (2010). PBS incubation, a simple technique to release miracidia of Opisthorchis-like eggs for DNA extraction. Exp. Parasitol. 124: 357-359.

Cary SC (1996). PCR-based method for single egg and embryo identification in marine organisms. Biotechniques 21: 998-1000.

Charles MM (1967). Identification and descriptions of Aedes eggs from California and Nevada (Diptera: Culicidae). Can. Entomol. 99: 795-806.

Chung C (1997). A simple method for determining the identity of the eggs of Aedes aegypti (Linnaeus) and Aedes albopictus (Skuse) by dissection (Diptera: Culicidae). Chin. J. Entomol. 17: 86-91.

Desloire S, Valiente MC, Chauve C and Zenner L (2006). Comparison of four methods of extracting DNA from $D$. gallinae (Acari: Dermanyssidae). Vet. Res. 37: 725-732.

Dobson SL and Rattanadechakul W (2001). A novel technique for removing Wolbachia infections from Aedes albopictus (Diptera: Culicidae). J. Med. Entomol. 38: 844-849.

Duenngai K, Sithithaworn P, Rudrappa UK, Iddya K, et al. (2008). Improvement of PCR for detection of Opisthorchis viverrini DNA in human stool samples. J. Clin. Microbiol. 46: 366-368.

Fantinatti ECS, Duque JEL, Silva AM and Silva-Navarro MA (2007). Abundância e agregação de ovos de Aedes aegypti L. e Aedes albopictus (Skuse) (Diptera: Culicidae) no norte e noroeste do Paraná. Neotrop. Entomol. 36: 954-960.

Forattini OP (1962). Entomologia Médica. Culicinea: Culex, Aedes e Psorophora. 1st edn. Edgard Blucher, São Paulo.

Giangrande A (2003). Biodiversity, conservation, and the taxonomic impediment. Aquatic Conserv. Mar. Freshwat. Ecosyst. 13: 451-459.

Gomes AC, Gotlieb SL, Marques CC, de Paula MB, et al. (1995). Duration of larval and pupal development stages of Aedes albopictus in natural and artificial containers. Rev. Saude Publica 29: 15-19.

Gubler DJ (2006). Dengue/dengue haemorrhagic fever: history and current status. Novartis Found. Symp. 277: 3-16.

Guedes DRD (2006). Epidemiologia Molecular do Aedes albopictus (Díptera: Culicidae). Master's thesis, Centro de Pesquisas Aggeu Magalhães, Memórias do Instituto Oswaldo Cruz, Recife.

Harrison RG (1989). Animal mitochondrial DNA as a genetic marker in population and evolutionary biology. Trends Ecol. Evol. 4: 6-11.

Hebert PD, Cywinska A, Ball SL and deWaard JR (2003). Biological identifications through DNA barcodes. Proc. Biol. Sci. 270: 313-321.

Hebert PD and Gregory TR (2005). The promise of DNA barcoding for taxonomy. Syst. Biol. 54: 852-859.

Miller SE (2007). DNA barcoding and the renaissance of taxonomy. Proc. Natl. Acad. Sci. U. S. A. 104: 4775-4776.

Nelson MJ (1986). Aedes aegypti: Biology and Ecology. Pan American Health Organization, Washington.

Nelson LA, Wallman JF and Dowton M (2007). Using COI barcodes to identify forensically and medically important blowflies. Med. Vet. Entomol. 21: 44-52. 
Paupy C, Ollomo B, Kamgang B, Moutailler S, et al. (2010). Comparative role of Aedes albopictus and Aedes aegypti in the emergence of Dengue and Chikungunya in central Africa. Vector Borne Zoonotic. Dis. 10: 259-266.

Pinto SB, Stainton K, Harris S, Kambris Z, et al. (2013). Transcriptional regulation of Culex pipiens mosquitoes by Wolbachia influences cytoplasmic incompatibility. PLoS Pathog. 9: e1003647.

Reinert JF (1972). Description of the Egg of Aedes (Aedimorphus) domesticus (Theobald) (Diptera: Culicidae). Mosq. Syst. 4: 60-62.

Sato M, Thaenkham U, Dekumyoy P and Waikagul J (2009). Discrimination of O. viverrini, C. sinensis, H. pumilio and $H$. taichui using nuclear DNA-based PCR targeting ribosomal DNA ITS regions. Acta Trop. 109: 81-83.

Staden R (1996). The Staden sequence analysis package. Mol. Biotechnol. 5: 233-241.

Stensvold CR, Saijuntha W, Sithithaworn P, Wongratanacheewin S, et al. (2006). Evaluation of PCR based coprodiagnosis of human opisthorchiasis. Acta Trop. 97: 26-30.

Swartz SS and Hebert PDN (1987). Methods for the activation of the resting eggs of Daphnia. Freshw. Biol. 17: 373-379.

Traub RJ, Macaranas J, Mungthin M, Leelayoova S, et al. (2009). A new PCR-based approach indicates the range of Clonorchis sinensis now extends to Central Thailand. PLoS Negl. Trop. Dis. 3: e367.

Umesha KR, Kumar S, Parvathi A, Duenngai K, et al. (2008). Opisthorchis viverrini: detection by polymerase chain reaction (PCR) in human stool samples. Exp. Parasitol. 120: 353-356.

Walsh PS, Metzger DA and Higuchi R (1991). Chelex 100 as a medium for simple extraction of DNA for PCR-based typing from forensic material. Biotechniques 10: 506-513.

Yue GH and Orban L (2001). Rapid isolation of DNA from fresh and preserved fish scales for polymerase chain reaction. Mar. Biotechnol. 3: 199-204. 